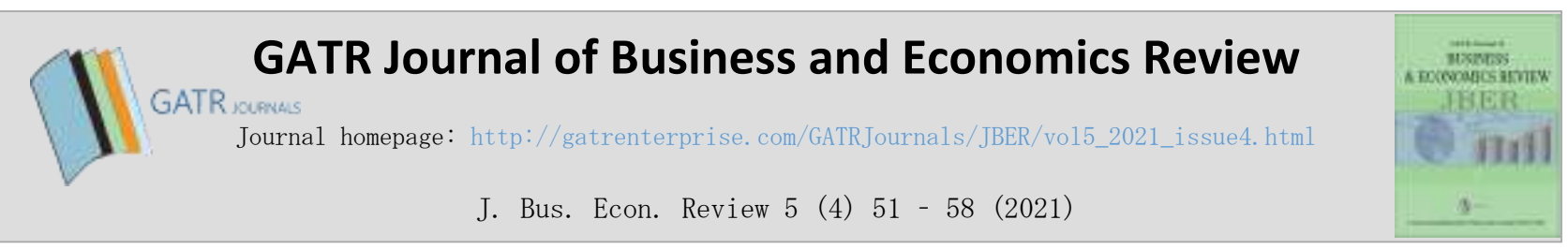

\title{
The Technology and Knowledge Spillover Effects of FDI on Labour Productivity
}

\author{
Norhanishah Mohamad Yunus $^{1^{*},}$ Noraida Abdul Wahob ${ }^{2}$ \\ ${ }^{1}$ School of Distance Education, Universiti Sains Malaysia, Malaysia,11800, Pulau Pinang Malaysia \\ ${ }^{2}$ Unit Peneraju Agenda Bumiputera, Prime Minister's Department,47810, Petaling Jaya, Selangor, Malaysia
}

\begin{abstract}
Objective - The purpose of this study is to investigate both "technology" and "knowledge" effects of foreign direct investment (FDI) on labour productivity in the medium-high manufacturing industries' classification in Malaysia.

Methodology/Technique -This study employs a Seemingly Unrelated Regression (SUR) estimator.

Findings - The results conclude that diffusion of knowledge, which increases labour productivity, is greater via "learning effects" as compared to the investor countries' capital investments in the medium-high manufacturing industries.

Novelty - This study expands the body of knowledge about the benefits of FDI spillovers on labour productivity according to specific investor countries, however, are rarely researched particularly in developing countries and at the industry level.
\end{abstract}

Type of Paper: Empirical.

JEL Classification: E60, J24

Keywords: Foreign Direct Investment; Labour Productivity; Technology Spillovers; Knowledge Spillovers

Reference to this paper should be made as follows: Yunus,N.M; Wahob, N.A. (2021). The Technology and Knowledge Spillover Effects of FDI on Labour Productivity, J. Bus. Econ. Review, 5(4) 51-58. https://doi.org/10.35609/jber.2021.5.4(5)

\section{Introduction}

The Malaysian Government has given recognition to the importance of joint investments in human capital $\mathrm{R} \& \mathrm{D}$ and the role of foreign direct investment (FDI) in encouraging higher labour productivity and sustainable competitive advantages, thus attracting a high level of FDI over the years. Even though Malaysia is one of the major FDI recipients in Southeast Asia and international technology transfer is considered as an imported mode for technology acquisition in a developing country like Malaysia, but the benefits of FDI spillovers on labour productivity in Malaysia remain ambiguous (Yunus \& Masron. 2020). This raises a question regarding the real benefits of technology spillovers from FDI that Malaysia is able to reap from their presence.

\footnotetext{
* Paper Info: Revised: December 25, 2020
} 


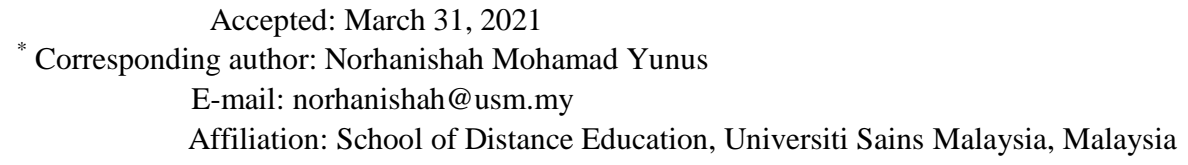

In this paper, we aim to enhance the extant literature in two ways. First, we attempt to address the gaps by investigate both technology and knowledge effects in line with our aim to study whether and how inward spillover effects of FDI do influence the labour productivity. Most of the studies only heavily emphasised on 'technology' effects rather than 'knowledge' effects on the host country as a result of the presence of foreign technology (Araújo, Bogliacino \& Vivarelli, 2009; Yunus et. al., 2015; Djulius, 2017; Yunus \& Masron, 2020. Second, this study aims to add to the existing literature by assessing FDI spillovers from major investor countries in Malaysia. To the author's best knowledge, only a few recent studies explored the literature of FDI effects from country spillovers in influencing labour productivity (e.g: Wang \& Mu, 2012; Liu et. al., 2001). The evidence of spillover effects of FDI inflows from specific country have focused on the firm's productivity either in developed or developing countries (e.g: Zhang et. al., 2010; Hu \& Jefferson, 2002)). Globalisation and liberalisation have seen trade and investment activities boom, thus increasing multilateral relations between Malaysia and other countries regardless of their level of development. Thus, this study may help the Malaysian government to justify the cost that should be invested to attract more FDI inflows towards the manufacturing industries in the short run.

In the context of Malaysia, an investigation on the potential policy to attract FDI inward in the short run is important as Malaysia begins to acknowledge the viable integration between skill upgrading and technology development capacity through FDI (Yunus, 2020). The outline for the rest of this study is as follows. Section 2 provides a review of the literature. In Section 3, we present the data discription and estimation method. Section 4 then outlines the results and discussion. Finally, in Section 5, we close the paper with a conclusion.

\section{Literature Review}

The evolutionary theory was the first theory that discussed the spillover effects of FDI. It was first introduced in the 1980s by Nelson (1982) and later by Conner (1991). This theory was also examined by Cantwell (2000), showing the foreign activities of MNCs and the spillover effects on the development of host economies. According to Cantwell (2000), the positive effect of spillovers tends to be higher for those host countries which have a higher absorptive capacity and have some traditional technological strength. This theory shows that those firms that have positive spillover effects tend to maintain their competitive power due to the learning effect from FDI which enables the firms to assimilate and absorb the high technology. The theory of Multinational Enterprises (MNEs) believes that MNEs act as an important source of technology transfer through foreign ownership, since one motive for FDI is to profit from utilising firmspecific technology-intensive assets in many countries. The MNEs may affect the host countries through skill-biased technological change and relative demand for skilled labour.

However, Slaughter (2002) reveals that, the method of FDI entry in influencing the development of human capital, for the improvement of skills in terms of supply is much clearer, either at the micro or macro level. Only a few studies paid attention to estimate how FDI stimulates the demand and supply of skills through technology transfer. According to Buckley, Clegg and Wang (2007), the technology spillovers via FDI is a principle source of positive spillovers for host counties, whether in developed or developing economies. Such advanced technology from FDI may spill over to domestic firms and improve the performance of the host country (Dunning \& Rugman, 1985). Bruno, Crinò and Falzoni (2012) show that foreign capital contributes to the capture process and causes technological and organisational improvements, which drive the restructuring process, thus increasing demand and supply of skills. Radošević and Rozeik (2004) show that foreign capital contributed to the catching-up process and led to technological and organisational 
improvement, which fostered the restructuring process, thereby increasing both the demand and supply of skills.

The positive impact of FDI on the labour productivity of the host industry is generally achieved through the formation of technology, management skills and techniques, and the impact of capital and spillovers on local firms (Liu et al., 2001). Research on the impact of the spillovers of FDI on employee productivity, however, is not yet available in the empirical literature. Most of the previous studies focused on the domestic firm's productivity and found mixed results. For instance, Castellani and Zanfei (2003) found positive and significant externalities on Italian firms, negative impact on Spanish firms, and non-significant effects on French firms. They continued the analysis to find anything that can be generalised to all countries by testing the implication of productivity gap between foreign and domestic firms, and absorptive capacity of domestic firms. Nonetheless, some studies did not find significant spillover effects on domestic productivity like Kokko, Tanzini and Zejan (1996) on Uruguayan manufacturing sector, Aslanoglu (2000) on Turkey manufacturing industries, Haddad and Harrison (1993) on Morocco manufacturing industries, and Aitken and Harrison (1999) on Venezuela manufacturing industries.

With regard to empirical evidence of spillover effects of FDI by country, Branstetter (2006) shows that capital investment acted as an effective channel for knowledge spillover from Japanese MNEs to firms in the United States. In contrast, Todo, Zhang, and Zhou (2009) found that Japanese MNEs do not contribute highly to knowledge spillovers, despite the increasing number of skilled workers in Chinese manufacturing firms. Nevertheless, they found that spillover effects from US MNEs were effective in enhancing the share of skilled labour in Chinese manufacturing firms. A study by Blomström, Fors, and Lipsey (1997) shows that the presence of Swedish MNCs in the United States and Sweden prompted a significant effect for skills upgrading on blue-collar employees in parent companies. The effects on white-collar employees within the Swedish firms became noticeably smaller and weaker over time.

Meanwhile, the effects of spillovers with respect to country spillovers, studies on the impact of the spillovers of FDI inflows from certain countries on labour productivity are not yet available in the empirical literature and are still under surveillance, especially at the industrial level. For example, Liu et. al. (2001) report that the presence of foreign firms in 41 Chinese electronics industry sub-sectors increased employee productivity. This study emphasises that the benefits of FDI depend on the technological capabilities of local firms, so that in order to get the most out of FDI, domestic firms must have greater technological capabilities. Similar results of the positive effects of FDI on employee productivity have also been reported in other studies (Kokko, 1994; Blomstrom \& Persson, 1983; Blomstrom \& Wolff, 1994). Using data covering 41 developing countries for the period of 2005 to 2008 to assess the extent to which technological overflow from the US affects labour productivity in selected developing countries, Wang and $\mathrm{Mu}$ (2012) found that the relationship between technological spillovers and labour productivity in developing countries is very sensitive to model specifications and budgeting techniques. Moderately collected data estimates show a clear relationship between technological spillovers and labour productivity, while more complex models such as dynamic panel data models fail in this task. The results of their analysis show that only imports have a significant impact on employee productivity.

In the context of Malaysia, to date, there are no studies on the spillover effects of FDI as classified by specific investor countries. Most recent studies specifically focused on the effects of FDI on labour productivity itself and at a high aggregate level (e.g: Sulaiman, Azman \& Ismail ; 2016; Yunus \& Hamid, 2019; Yunus \& Masron, 2020).

\section{Data Description and Estimation Method}

The main data sources in this study came from the Department of Statistics Malaysia (DOSM) and the Malaysian Industry and Development Authority (MIDA) based on a manufacturing survey on industries 
between 2000 and 2018. The combination of model specification by Liu, Parker, Vaidya, and Wei (2001), Bronzini and Piselli (2009) and Ballot et. al. (2001), are used to examine the FDI spillover effects and other variables factors that influence labour productivity. The labour productivity function in the medium-hightechnology industries can be expressed as:

$\ln L P_{i t=} \ln A_{i t}+B_{1} \ln \left(\frac{K}{L}\right)_{i t}+B_{2} \ln T E C H_{i t j}+B_{3} \ln E M P_{i t j}+B_{4} \ln X_{i t}+\varepsilon_{i t}$

where: $i$ is an index of industry including Electronics and Electrical (E\&E), Chemical, Machinery and Equipment, and Transport Equipment. $\mathrm{t}$ is time index. $\mathrm{j}$ is an index of country's spillovers (Japan,China, Singapore, Taiwan and the United States). LP refers to labour productivity. $\frac{K}{L}$ is the ratio of capital to worker $(\mathrm{K} / \mathrm{L})$ or capital intensity approximated by gross investments in fixed capital per worker. TECH is the foreign capital investment by investor countries and EMP (number of local workers in the MNCs). X represents other factors commonly considered in discussing labour productivity, namely are :level of educational attainment, cost of training per employee, R\&D investment, direct domestic investment from domestic investors, share of ICT investment, and FS denoting firm size (industrial sales revenue of the sub-sector divided by the number of total firms . $\varepsilon_{i t}$ is an error term that captures the time varying firm specific productivity shocks.

\section{Estimation Method: Seemingly Unrelated Regression (SUR) Estimator}

With the limitation in panel data at a 2-digit industry level, such as in our case of 266 observations, we employed a seemingly unrelated regression (SUR) estimator; one of the panel data estimation methods (Zellner, 1963; Zellner, 1962). In this study, SUR is the best method in estimating panel data models as the number of industries $(N)=5$ industries is bigger than year $(T)=19$.

When estimating the SUR model, the data must be arranged as a time series (not a panel) with different variables listed separately. In the basic SUR model, the errors are assumed to be homoscedastic and linearly independent within each equation. By applying this method, the outcome of this analysis is perhaps useful in providing a preliminary picture of the levels of Malaysian skills required to absorb the spillover effects of FDI. This study can then identify which spillover effects of FDI have more influence on the Malaysian labour productivity by considering that the error terms' correlations across equations lead to better predictions of future values of the dependent variables. The SUR estimator provides the lowest standard errors of the estimated parameters and thus, the highest precision of the estimates (Zellner, 1963; Zellner, 1962).

\section{Results and Discussion}

Before the outcome of the SUR estimation is discussed, the most important point to highlight is the validity of the use of SUR application. This can be done via the test of contemporaneous correlation if each equation is estimated by using ordinary least square (OLS) in Table 1. The results of Breusch-Pagan Lagrange Multiplier (BP-LM) test in model (1) confirmed that there was a presence of contemporaneous correlation and hence, validate the use of SUR approach. Model SUR in model (2) shown the labour productivity analysis by looking at "technology" and "knowledge" effects by country's spillovers. We found coefficients value of "technology" by Japanese, American and Singaporean MNCs were significant in influencing labour productivity with a negative sign while positive sign for knowledge effects. The negative impact was, however, too small as the coefficient was less than $0.10 \%$. These results indicate that technology spillover effects minimally increased labour productivity in the Malaysian medium-high industries, thus implying that the local workers' ability to imitate and adopt high-skill-based technologies from MNCs. The stagnancy in technological transfer can be attributed to the lack of highly- skilled and well-trained local human resource, which in turn adversely affects labour productivity. 


\begin{tabular}{|c|c|c|}
\hline \multicolumn{3}{|c|}{ Dependant Variables: Labour Productivity } \\
\hline Variables & Model OLS & Model SUR \\
\hline Capital/labour & $0.263(0.062)^{* * *}$ & $0.273(0.033)^{* * *}$ \\
\hline \multicolumn{3}{|c|}{ Technology Spillover Effects by Investor Countries } \\
\hline Japan & $-0.034(0.039)$ & $-0.013(0.025)^{*}$ \\
\hline Singapore & $0.0153(0.058)$ & $-0.016(0.034)^{* *}$ \\
\hline United of States & $0.006(0.031)$ & $-0.005(0.021)^{*}$ \\
\hline Taiwan & $-0.043(0.034)$ & $0.018(0.015)$ \\
\hline China & $-0.039(0.037)$ & $0.011(0.011)$ \\
\hline \multicolumn{3}{|c|}{ Knowledge Spillover Effects (No. of Local Employment in the MNCs by Investor Countries } \\
\hline Japan & $-0.0025(0.031)$ & $0.034(0.033) * *$ \\
\hline Singapore & $-0.0079(0.040)$ & $0.012(0.048) * * *$ \\
\hline United of States & $-0.005(0.025)$ & $0.016(0.0258)^{* *}$ \\
\hline
\end{tabular}

Table 1: Result of OLS and SUR Analysis in Medium -High Industry, 2000-2018 


\begin{tabular}{|l|c|c|}
\hline Taiwan & $0.018(0.018)$ & $-0.047(0.028)$ \\
\hline China & $0.001(0.028)$ & $0.049(0.033)$ \\
\hline Control Variables & & $0.395(0.017)^{* *}$ \\
\hline Share of degree & $0.436(0.216)^{* *}$ & $-0.334(0.213)^{* * *}$ \\
\hline Share of diploma & $-0.351(0.155)^{* *}$ & $0.049(0.077)$ \\
\hline Share of Middle Certificate Education/Vocational & $0.077(0.119)$ & $0.164(0.047)^{* * *}$ \\
\hline Training Cost & $0.171(0.058)^{* * *}$ & $-0.037(0.046)^{* *}$ \\
\hline R\&D Expenditure & $-0.096(0.032)^{* * *}$ & $0.232(0.067)^{* * *}$ \\
\hline Firm Size & $0.237(0.078)^{* * *}$ & $-0.037(0.046)^{* *}$ \\
\hline Domestic investment & $-0.034(0.059)$ & $0.123(0.012)^{* * *}$ \\
\hline Information technology expenses & $0.116(0.052)^{* *}$ & $7.055(0.043)^{* * *}$ \\
\hline Constant & $6.884(0.213)^{* * *}$ & 76 \\
\hline Observations & 76 & 0.912 \\
\hline R-squared & 0.832 & - \\
\hline Breusch and Pagan LM test & 17.23 & - \\
\hline Prob>chi2 & 0.5742 & \\
\hline
\end{tabular}

Notes: All variables are transformed into natural log. Bootstrapped standard errors for SUR in parentheses. ***p < $0.01, * * \mathrm{p}<0.05, * \mathrm{p}<0.1$.

In terms of knowledge spillover effects, Singaporean and American MNCs showed a particular pattern to that of Japanese MNCs. All investor countries' spillovers benefitted the local workers' skills upgrading, which was then translated into higher productivity in the medium to high industries. Even through the presence of both Singaporean and American MNCs increased labour productivity by $1.2 \%$ and $1.6 \%$ respectively, this slight increase still testifies to the existence of improved skills and capacity of workers to assimilate the skills learned (e.g: through the imitation process, movement of knowledge skills, organisation values, and capital from the point of generation to the site of adoption and application) (Mittelman \& Pasha, 1997). Previous studies supported that the upgrading of local personnel is also another means by which MNCs have helped the process of transferring technologies to Malaysia. This is most evident in American MNCs such as Intel, Motorola or National Semiconductor that formally employed many of the managers of Malaysian-owned semiconductor assembly sub-contractors such as Carsem and Unisem. Thus, the local managers in American MNCs were able to acquire all the skills needed to run the entire operation of the subsidiaries (Ismail, 2001).

Lastly, our findings on the Chinese and Taiwanese MNCs' spillover effects case are surprisingly inconsistent with the findings of Buckley, Clegg and Wang (2002). They claimed that the higher the foreign capital participation, the greater the productivity. We, however, found that the Chinese and Taiwanese MNCs in Malaysia were statistically insignificant in influencing Malaysian labour productivity in the medium-high industry. This result suggested that the technology and knowledge transferred from these countries' MNCs to the local firms did not contribute to the local workers' skills upgrading. This may be due to Malaysia's manufacturing sector suffering from negative backward and forward spillover effects brought about by China's investment (Dogan, Wong \& Yap, 2017).

For other determinants influencing labour productivity, similar to Yunus et. al. (2014), we conclude that the influence of training, $R \& D$ investment, employees with diploma and degree holders, ICT investment, and firm size significantly influence labour productivity. Nonetheless, the coefficients of R\&D investment and domestic investment from local investors showed statistically negative impact on labour productivity in the medium-high industries. The negative impact was, however, too small as the coefficient is less than $0.05 \%$. Possible reasons for this negative impact include low level of innovation efficiency, technological capacity in this industry, and the existence of crowding-out effects. The crowding-out effects occurred when the 
increased amount of R\&D investment and direct domestic investments drive away the inflows of FDI .This goes to show that both foreign and domestic investments are of equal importance as one affects the other in an economy, and thus influence labour productivity (Yunus \& Hamid, 2019).

\section{Conclusion}

We provide additional evidence concerning "technology" and "knowledge" spillover effects of FDI on labour productivity. There are no positive spillover of technological effects in the medium-high industries from all investor countries selected in this study. These findings contradicted the argument put forward by Smarzynska (2002), stating that MNCs tend to locate their operation in highly productive industries.

In examining whether technology and knowledge spillovers increase the local workers' productivity, we found that the impact of knowledge spillovers from all investor countries to be higher than the impact of technology spillovers. Based on the main investor countries revealed that local workers were most able to assimilate and absorb higher knowledge from Japanese firms, followed by American and Singaporean firms, in the medium-high industries. We can conclude that the differences in the amount of knowledge transfer between investor countries depend on the extent of technology transfer practices traded by foreign companies in local firms. This will ultimately affect labour productivity.

Recognising that improvements in labour productivity are important to ensure that manufacturers remain competitive in line with industry 4.0 requirements, we conclude that technology and knowledge from FDI spillovers can potentially increase labour productivity, but the success of transferring knowledge and technology highly depends on the employees' absorption capacities. Thus, to increase the capacity of absorption, this study suggests that employers provide monetary incentive or personal rewards to employees who can successfully transfer their FDI's knowledge and technology through the demonstration and competition effects to other employees. The present study also suggests that education and training should be complementary to the technological change to solve for the available skill that is no longer required by firms, as well as the short fall in the skills available for workers.

\section{Acknowledgement}

This work was supported by Universiti Sains Malaysia under the Short-Term Research Grant Scheme No. 304/PJJAUH/6315270. This is the revised version of a paper presented at the 11th Global Conference on Business and Social Sciences hosted by Global Academy of Training \& Research, held in Bangkok, Thailand, 11-12 December 2020. We thank the anonymous reviewers for their feedback in improving this paper.

\section{References}

Allison, P. D. (2009). Fixed effects regression models. SAGE publications. https://doi.org/10.4135/9781412993869

Aitken, B. J., \& Harrison, A. E. (1999). Do domestic firms benefit from direct foreign investment? Evidence from Venezuela. American economic review, 89(3), 605-618.https://doi.org/10.1257/aer.89.3.605

Araujo, B., Bogliacino, F., \& Vivarelli, M. (2009). The Role of'Skill Enhancing Trade'in Brazil: Some Evidence from Microdata.

Aslanoğlu, E. (2000). Spillover effects of foreign direct investments on Turkish manufacturing industry. Journal of International Development: The Journal of the Development Studies Association, 12(8), 1111-1130. https://doi.org/10.1002/jid.701

Ballot, G., Fakhfakh, F., \& Taymaz, E. (2001). Firms' human capital, R\&D and performance: a study on French and Swedish firms. Labour economics, 8(4), 443-462. https://doi.org/10.1016/S0927-5371(01)00038-0 
Blomström, M., Fors, G., \& Lipsey, R. E. (1997). Foreign direct investment and employment: home country experience in the United States and Sweden. The Economic Journal, 107(445), 1787-1797. https://doi.org/10.1111/j.14680297.1997.tb00082.x

Blomström, M., \& Persson, H. (1983). Foreign investment and spillover efficiency in an underdeveloped economy: evidence from the Mexican manufacturing industry. World development, 11(6), 493-501. https://doi.org/10.1016/0305750X(83)90016-5

Blomström, M., Kokko, A., \& Zejan, M. (2000). Multinational corporations and productivity convergence in Mexico. In Foreign Direct Investment (pp. 134-159). Palgrave Macmillan, London. https://doi.org/10.3386/w3141

Branstetter, L. (2006). Is foreign direct investment a channel of knowledge spillovers? Evidence from Japan's FDI in the United States. Journal of International economics, 68(2), 325-344. https://doi.org/10.1016/j.jinteco.2005.06.006

Bronzini, R., \& Piselli, P. (2009). Determinants of long-run regional productivity with geographical spillovers: the role of R\&D, human capital and public infrastructure. Regional Science and Urban Economics, 39(2), 187199.https://doi.org/10.1016/j.regsciurbeco.2008.07.002

Bruno, G. S., Crinò, R., \& Falzoni, A. M. (2012). Foreign Direct Investment, Trade, and Skilled Labour Demand in E astern E urope. Labour, 26(4), 492-513.doi: 10.1111/labr.12001.

Buckley, P. J., Clegg, J., \& Wang, C. (2002). The impact of inward FDI on the performance of Chinese manufacturing firms. Journal of international business studies, 33(4), 637-655. https://doi.org/10.1057/palgrave.jibs.8491037

Cantwell, J. (2000). A survey of theories of international production. The nature of the transnational firm, 2.

Castellani, D., \& Zanfei, A. (2003). Technology gaps, absorptive capacity and the impact of inward investments on productivity of European firms. Economics of Innovation and New Technology, 12(6), 555-576. https://doi.org/10.1080/714933761

Conner, K. R. (1991). A historical comparison of resource-based theory and five schools of thought within industrial organization economics: do we have a new theory of the firm?. Journal of management, 17(1), 121-154.

Djulius, H. (2017). Foreign direct investment and technology transfer: Knowledge spillover in the manufacturing sector in Indonesia. Global Business Review, 18(1), 57-70. https://doi.org/10.1177/0972150916666878

Dogan, E., Wong, K. N., \& Yap, M. M. (2017). Vertical and horizontal spillovers from foreign direct investment: evidence from Malaysian manufacturing. Asian Economic Papers, 16(3), 158-183. https://doi.org/10.1162/asep_a_00560

Dunning, J. H., \& Rugman, A. M. (1985). The influence of Hymer's dissertation on the theory of foreign direct investment. The American Economic Review, 75(2), 228-232.

Haddad, M., \& Harrison, A. (1993). Are there positive spillovers from direct foreign investment?: Evidence from panel data for Morocco. Journal of development economics, 42(1), 51-74. https://doi.org/10.1016/0304-3878(93)90072-U

Hu, A. G., \& Jefferson, G. H. (2002). FDI impact and spillover: evidence from China's electronic and textile industries. the world Economy, 25(8), 1063-1076. https://doi.org/10.1111/1467-9701.00481

Ismail, M. N. (2001). Foreign direct investments and development: The Malaysian electronics sector. Chr. Michelsen Institute.

Kokko, A., Tansini, R., \& Zejan, M. C. (1996). Local technological capability and productivity spillovers from FDI in the Uruguayan manufacturing sector. The Journal of Development Studies, 32(4), 602-611. https://doi.org/10.1080/00220389608422430

Liu, X., Parker, D., Vaidya, K., \& Wei, Y. (2001). The impact of foreign direct investment on labour productivity in the Chinese electronics industry. International business review, 10(4), 421-439.https://doi.org/10.1016/S09695931(01)00024-5

Ministry of International Trade and Industry. (2018). National Policy on Industry 4.0. Ministry of International Trade and Industry. Kuala Lumpur, Malaysia: Author.

Mittelman, J. H., \& Pasha, M. K. (1997). Back to the Nineteenth Century for New Ideas. In Out from Under development Revisited (pp. 80-101). Palgrave Macmillan, London. https://doi.org/10.1007/978-1-349-25183-4_4

Nelson, R. R. (1982). The role of knowledge in R\&D efficiency. The Quarterly Journal of Economics, 97(3), 453-470. https://doi.org/10.2307/1885872

Radosevic, S., \& Rozeik, A. (2005). Foreign direct investment and restructuring in the automotive industry in Central and East Europe. 
Slaughter, M. J. (2002). Does inward foreign direct investment contribute to skill upgrading in developing countries?. Center for Economic Analysis Working Paper (2002-08).

Smarzynska Javorcik, B. (2004). Does foreign direct investment increase the productivity of domestic firms? In search of spillovers through backward linkages. American economic review, 94(3), 605-627. DOI: $10.1257 / 0002828041464605$

Sulaiman, N., Azman, N. M., \& Ismail, R. (2016). The Impact of Globalization on Labor Productivity in the Services Sector. Malaysian Economic Journal, 50 (2), 71-81.

Todo, Y., Zhang, W., \& Zhou, L. A. (2009). Knowledge spillovers from FDI in China: The role of educated labor in multinational enterprises. Journal of Asian Economics, 20(6), 626-639. https://doi.org/10.1016/j.asieco.2009.09.002

Wang, Y., \& Mu, B. (2012). How technology spillovers from developed to developing countries influence labor productivity in developing countries.

Yunus, N. M. (2017). Sheepskin effects in the returns to higher education: New evidence for Malaysia. Asian Academy of Management Journal, 22(1), 151.https://doi.org/10.21315/aamj2017.22.1.7.

Yunus, N. M. (2020). Determinants of Foreign Direct Investment: An Analysis on Policy Variables in the Malaysian Manufacturing Industry. International Journal of Asian Social Science, 10(12), 746-760. https://doi.org/10.18488/journal.1.2020.1012.746.760

Yunus, N. M., \& Hamid, F. S. (2003). Changing returns to education in the Malaysian Electric \& Electronic sector, 2002-2007. organization, 3.

Yunus, N. M., \& Hamid, F. S. (2019). Training, Research and Development, and Spillover Effects of Foreign Direct Investment: A Study on Labour Productivity in Malaysian Manufacturing Industry. Int. J Sup. Chain. Mgt Vol, 8(3), 966.

Yunus, N. M., \& Masron, T. A. (2020). Spillover Effects of Inward Foreign Direct Investment on Labour Productivity: An Analysis on Skill Composition in Manufacturing Industry. International Journal of Asian Social Science, 10(10), 593-611. https://doi.org/10.18488/journal.1.2020.1010.593.611

Yunus, N. M., Said, R., \& Azman-Saini, W. N. W. (2015). Spillover effects of FDI and trade on demand for skilled labour in Malaysian manufacturing industries. Asian Academy of Management Journal, 20(2), 1-27.

Yunus, N. M., Said, R., \& Hook, L. S. (2014). Do cost of training, education level and R\&D investment matter towards influencing labour productivity. Jurnal Ekonomi Malaysia, 48(1), 133-142.https://doi.org/10.17576/jem2014-4801-11.

Zellner, A. (1962). An efficient method of estimating seemingly unrelated regressions and tests for aggregation bias. Journal of the American statistical Association, 57(298), 348-368.https://doi.org/10.1080/01621459.1962.10480664

Zellner, A. (1963). Estimators for seemingly unrelated regression equations: Some exact finite sample results. Journal of the American Statistical Association, 58(304), 977-992.https://doi.org/10.1080/01621459.1963.10480681

Zhang, Y., Li, H., Li, Y., \& Zhou, L. A. (2010). FDI spillovers in an emerging market: the role of foreign firms' country origin diversity and domestic firms' absorptive capacity. Strategic Management Journal, 31(9), 969-989. https://doi.org/10.1002/smj.856 